ISSN 0258-7122 (Print), 2408-8293 (Online)

Bangladesh J. Agril. Res. 41(3): 541-554, September 2016

\title{
NUTRITIVE VALUE AND YIELD POTENTIAL OF OKRA (Abelmoschus esculentus L. Moench) GENOTYPES
}

\author{
A. BISWAS ${ }^{1}$, M. M. HOSSAIN ${ }^{2}$, Z. ALAM ${ }^{3}$ \\ M. M. ISLAM ${ }^{4}$ AND A. BISWAS ${ }^{5}$
}

\begin{abstract}
Two experiments were conducted at the research field and laboratory of the Department of Horticulture, Bangabandhu Sheikh Mujibur Rahman Agricultural University, Salna, Gazipur, during April 2012 to September 2013 to find out the yield performance and nutritional quality of seven genotypes of okra in Bangladesh. The results revealed that the highest yield of okra obtained from BARI Dherosh1 (14.9 t/ha) and the lowest yield was obtained from Hybrid Raja $(5.76 \mathrm{t} / \mathrm{ha})$. The highest fruits per plant were recorded from BARI Dherosh1 (24.27 fruits/plant). The genotype Green Hybrid produced the lowest edible fruit per plant (10.27). Maximum virus infestation was recorded in genotype Hybrid Raja (100\%) and the lowest in Arka Anamika (76.67\%) as well as Arka Anamika performed well in many aspect such as yield (12.95 t/ha), fruits per plant (19.83), number of branches per plant (6). The highest content of free ascorbic acid was recorded in Nabik $(3.35 \mathrm{mg} / 100 \mathrm{gm})$ and the minimum ascorbic acid content was observed in Green Hybrid $(1.987 \mathrm{mg} / 100 \mathrm{~g})$. Hybrid Moti had the maximum amount of $\beta$-carotene $(0.15 \mathrm{IU} / 100 \mathrm{~g})$, while minimum amount of $\beta$-carotene was found in IPSA Okra $(0.09 \mathrm{IU} / 100 \mathrm{~g})$. The highest $\mathrm{K}$ content was observed in IPSA Okra $(1.091 \%)$ and the lowest in Hybrid Raja $(1.06 \%)$. The highest amount of Fe was observed in Hybrid Moti (139.60 ppm) and the lowest amount of Fe was observed in Green Hybrid (111.80 ppm). The present results revealed that the yield was maximum in BARI Dherosh1 while Hybrid Moti was superior in nutritive value.
\end{abstract}

Keywords: Okra genotype(s), nutritive value, yield potentiality.

\section{Introduction}

Okra (Abelmoschus esculentus L. Moench) is a popular green fruit vegetable in Bangladesh. It is commonly known as bhendi or lady's finger in Bangladesh (Rashid, 1999). It is the choicest fruit vegetable grown extensively in tropical, subtropical and warm area of the temperate zones of the world (Tindall, 1983; Siemonsma and Kouame, 2004). Being native of tropical Africa, it is widely cultivated as an important vegetable crop in Bangladesh. Okra is very popular for

\footnotetext{
${ }^{1}$ MS Student, Department of Horticulture, Bangabandhu Sheikh Mujibur Rahman Agricultural University (BSMRAU), Gazipur, ${ }^{2}$ Professor, Department of Horticulture, BSMRAU, Gazipur, ${ }^{3 \& 4}$ Scientific Officer, Tuber Crops Research Centre, BARI, Gazipur, ${ }^{5}$ Scientific Officer, Regional Agricultural Research Station, Bangladesh Agricultural Research Institute (BARI), Jessore, Bangladesh.
} 
its delicious, tasty, gelatinous, tender, fruits as vegetable. 3-5 days old tender green pods are used as a vegetable, generally marketed in the fresh state. It is the best source of iodine and calcium. Consumption of $100 \mathrm{~g}$ of fresh okra fruit provides 20,15 and $50 \%$ of the daily requirement of calcium, iron and ascorbic acid, respectively (Schippers, 2002). Okra is a popular health food due to its high fiber, and vitamin $\mathrm{C}$ content. It is also known for being high in antioxidants. It is also a good source of calcium and potassium (Duvauchelle, 2011). Greenishyellow edible okra oil is pressed from okra seeds; it has a pleasant taste and odor, and is high in unsaturated fats such as oleic acid and linoleic acid (Franklin, 1982).

Average yield of okra in this country is quite low because of the commercially cultivated low yielding varieties. High yield potential genotype with good characteristics is the basis of successful crop production and is important for increasing the productivity. So, in case of genotypes yield potential must be considered for commercial production. Different okra genotypes differ significantly for most of the traits like number of fruits, fruit length, fruit weight and fruit yield per plant, those ultimately determine overall yield of the variety or cultivar. A number of okra varieties are under cultivation in Bangladesh. Besides the improved cultural practices, there is a need to grow high yielding cultivars to increase the green fruit yield per plant and per unit area. In the present study seven okra genotype from local and exotic sources were evaluated for their yield potentiality and determined the nutritional quality of okra genotypes.

\section{Materials and Method}

The experiment was conducted at the Horticultural Research Farm, BSMRAU, Gazipur during the period from April 2012 to September 2013. Seven genotypes of okra viz. BARI Dherosh1, IPSA Okra 1, Green Hybrid, Nabik, Hybrid Raja, Arka Anamika and Hybrid Moti were used in this experiment. The field experiment was laid out in a Randomized Complete Block Design with three replications and the lab experiment was laid out in completely randomized design with three replications. The unit plot size was $4 \mathrm{~m} \times 1.5 \mathrm{~m}$. The genotypes of okra were collected from the respective organizations and the market of Siddique bazaar of Dhaka. The land was manured and fertilized with Cowdung, Urea, TSP, MoP and Molybdenum @ 1000, 150,100, 150 and 1kg/ha, respectively. The entire amount of Cow dung, $1 / 2$ Urea, TSP, $1 / 2 \mathrm{MoP}$ and Molybdenum were applied at the time of final land preparation and the rest of urea and MoP were applied as top dressing in three equal split at 20, 40 and 60 days after germination. The seeds of seven genotypes were sown on 11 April 2012 in the plots. The row spacing was $60 \mathrm{~cm}$ having plant spacing of $40 \mathrm{~cm}$ within the row. Weeding, irrigation and other cultural practices were done as and when necessary. The collected data on various parameters were statistically analyzed 
using MSTAT-C program and the significance was tested by ANOVA. The means of different parameters were compared by Duncan's Multiple Range Test (DMRT) at 5\% level of probability (Gomez and Gomez, 1984).

\section{Results and Discussions}

The analysis of variance showed that the genotypes under study differed significantly among themselves for all characters which are presented below:

\section{Plant height}

Plant height varies significantly at 25DAS, 40DAS, 55DAS and 70DAS among the genotypes (Table 1). Plant height obtained from genotypes at 25 DAS ranged from 11.31 to $16.13 \mathrm{~cm}$, at 40 DAS ranged from 27.17 to $37.77 \mathrm{~cm}$, at 55 DAS ranged from 43.43 to $64.33 \mathrm{~cm}$ and at 70 DAS ranged from 78.67 to $108 \mathrm{~cm}$. Highest plant height obtained from Hybrid Moti (16.13) which was statistically similar to Nabik $(15.27 \mathrm{~cm})$, Arka Anamika $(14.27 \mathrm{~cm})$ BARI Dherosh1 $(14.1 \mathrm{~cm})$, IPSA Okra $(14.1 \mathrm{~cm})$ while the lowest plant height obtained from Hybrid Raja $(11.31 \mathrm{~cm})$ which was statistically identical with Green hybrid $(12.83 \mathrm{~cm})$ at $25 \mathrm{DAS}$.

At 40 DAS Highest plant height obtained from Hybrid Moti $(37.77 \mathrm{~cm})$ which was statistically identical with Arka Anamika $(35.59 \mathrm{~cm})$ and BARI Dherosh1 $(35.17 \mathrm{~cm})$. The lowest plant height obtained from Hybrid Raja $(27.17 \mathrm{~cm})$ which was statistically identical with Nabik $(29.47 \mathrm{~cm})$.

Table 1. Plant height of different genotypes of okra at different days after sowing

\begin{tabular}{l|c|c|c|c}
\hline \multirow{2}{*}{\multicolumn{1}{c}{ Genotype }} & \multicolumn{4}{c}{ Plant height(cm) } \\
\cline { 2 - 5 } & $25 \mathrm{DAS}$ & $40 \mathrm{DAS}$ & $55 \mathrm{DAS}$ & $70 \mathrm{DAS}$ \\
\hline BARI Dherosh1 & $14.10 \mathrm{ab}$ & $35.17 \mathrm{ab}$ & $64.33 \mathrm{a}$ & $106.4 \mathrm{a}$ \\
IPSA Okra & $14.10 \mathrm{ab}$ & $33.43 \mathrm{bc}$ & $60.93 \mathrm{a}$ & $94.87 \mathrm{~b}$ \\
Green Hybrid & $12.83 \mathrm{bc}$ & $31.97 \mathrm{~cd}$ & $54.50 \mathrm{~b}$ & $86.20 \mathrm{bc}$ \\
Nabik & $15.27 \mathrm{a}$ & $29.47 \mathrm{de}$ & $52.47 \mathrm{~b}$ & $82.33 \mathrm{c}$ \\
Hybrid Raja & $11.31 \mathrm{c}$ & $27.17 \mathrm{e}$ & $43.43 \mathrm{c}$ & $70.07 \mathrm{~d}$ \\
Arka Anamika & $14.67 \mathrm{ab}$ & $35.59 \mathrm{ab}$ & $63.27 \mathrm{a}$ & $108.0 \mathrm{a}$ \\
Hybrid Moti & $16.13 \mathrm{a}$ & $37.77 \mathrm{a}$ & $63.13 \mathrm{a}$ & $78.67 \mathrm{~cd}$ \\
Level of significance & $*$ & $*$ & $*$ & $*$ \\
CV\% & 8.51 & 5.13 & 4.56 & 5.91 \\
\hline
\end{tabular}

Means bearing same letter(s) in a column do not differ significantly at $5 \%$ level of probability by DMRT.

At 55 DAS after sowing highest plant height obtained from BARI Dherosh1 $(64.33 \mathrm{~cm})$ which was statistically similar with Arka Anamika $(63.27 \mathrm{~cm})$, Hybrid Moti $(63.13 \mathrm{~cm})$ and IPSA Okra $(60.93 \mathrm{~cm})$. Lowest plant height obtained from Hybrid Raja (43.43 cm). 
At 70 DAS highest plant height obtained from Arka Anamika $(108.00 \mathrm{~cm})$ which was statistically identical to BARI Dherosh1 $(106.33 \mathrm{~cm})$. Lowest plant height obtained from Hybrid Raja $(70.07 \mathrm{~cm})$ which was statistically identical with Hybrid Moti $(78.67 \mathrm{~cm})$. Plant height of different genotypes varied due to inherent characteristics of genotype. Karri and Pinaki (2012) reported that the highest plant height during summer season was $100.62 \mathrm{~cm}$. Rahman et al. (2012) found highest plant height $91.33 \mathrm{~cm}$ under the evolutionary field trial of five okra genotype. Kuwar et al. (2001) reported highest plant height was $130.4 \mathrm{~cm}$; the present result is within the range of reported result. Plant height varied probably due to genotypical variation.

\section{Number of leaves}

Significant difference in number of leaves per plant was noticed among the genotypes (Table 2). The maximum number of leaves per plant obtained from IPSA Okra (8.83) which was statistically similar with BARI Dherosh1 (8.60), Arka Anamika (8.50) and Nabik (8.40) and minimum number of leaves obtained from Hybrid Raja (7.54) at 25DAS.

At 40 DAS maximum number of leaves obtained from Hybrid Moti (12.37) and minimum number of leaves obtained from Hybrid Raja (10.57) which was statistically similar with Arka Anamika (10.77) and IPSA Okra.

Table 2. Number of leaves of different genotypes of okra at different days after sowing

\begin{tabular}{l|c|c|c|c}
\hline \multirow{2}{*}{\multicolumn{1}{c}{ Genotype }} & \multicolumn{4}{c}{ Number of leaves } \\
\cline { 2 - 5 } & $25 \mathrm{DAS}$ & $40 \mathrm{DAS}$ & $55 \mathrm{DAS}$ & $70 \mathrm{DAS}$ \\
\hline BARI Dherosh 1 & $8.60 \mathrm{ab}$ & $11.10 \mathrm{bc}$ & $23.93 \mathrm{a}$ & $33.87 \mathrm{a}$ \\
IPSA Okra & $8.83 \mathrm{a}$ & $10.97 \mathrm{~cd}$ & $22.80 \mathrm{ab}$ & $30.67 \mathrm{~b}$ \\
Green Hybrid & $8.23 \mathrm{bc}$ & $11.27 \mathrm{bc}$ & $19.93 \mathrm{~cd}$ & $24.20 \mathrm{~d}$ \\
Nabik & $8.40 \mathrm{abc}$ & $11.53 \mathrm{~b}$ & $20.67 \mathrm{bcd}$ & $27.73 \mathrm{c}$ \\
Hybrid Raja & $7.54 \mathrm{~d}$ & $10.57 \mathrm{~d}$ & $18.93 \mathrm{~d}$ & $27.73 \mathrm{c}$ \\
Arka Anamika & $8.50 \mathrm{abc}$ & $10.77 \mathrm{~cd}$ & $21.90 \mathrm{abc}$ & $33.47 \mathrm{a}$ \\
Hybrid Moti & $8.03 \mathrm{c}$ & $12.37 \mathrm{a}$ & $20.90 \mathrm{bcd}$ & $27.07 \mathrm{c}$ \\
Level of significance & $*$ & $*$ & $*$ & $*$ \\
CV\% & 3.20 & 7.57 & 5.89 & 3.71 \\
\hline
\end{tabular}

Means bearing same letter(s) in a column do not differ significantly at 5\% level of probability by DMRT.

At 55 DAS after sowing maximum number of leaves obtained from BARI Dherosh 1(23.93) which was statistically similar with IPSA Okra (22.80) and Arka Anamika (21.90).Minimum number of leaves obtained from Hybrid Raja (18.93) which was statistically similar with Green Hybrid (19.93), Nabik (20.67) and Hybrid Moti (20.90). 
At 70 DAS maximum number of leaves obtained from BARI Dherosh1 (33.87) which was statistically similar with Arka Anamika (33.47) and minimum number of leaves obtained from Green Hybrid (24.20). Falusi et al. (2012) reported that average number of leaves at the time of maturity were 12.40 .The present result is higher than the reported result because of different genotype.

\section{Number of branches per plant}

The number of branches per plant showed significant variation (Fig.1) and Green Hybrid (6.27) was highest in this respect followed by Arka Anamika (6.00), BARI Dherosh1 (5.93). The lowest number of branches obtained from IPSA Okra (3.47) which was identical with Hybrid Moti (4.13) and Hybrid Raja (4.60). Number of branches per plant in this study varied from 3.47 to 6.27. Similar result was also reported by Kuwar et al. (2001).

\section{Days to anthesis}

As regards to days to anthesis, it was observed that it varied significantly among the genotypes and ranges from 41.33 to 46.67 days (Fig. 2). Earliest first opening of flower was recorded in BARI Dherosh1 (41.33 days) which was at par with Hybrid Moti (42.33 days), Arka Anamika (42.33 days) and IPSA Okra (43 day) while late first opening of flower was observed in Hybrid Raja (46.67 days) which was identical with Green Hybrid (46 days). Muhammad et al. (2001) reported the earliest flowering in 45 days in four high yielding okra genotypes.

\section{Days to 50\% flowering}

Seven genotypes showed significant variation in respect of $50 \%$ flowering. All the genotypes required 44.33 days to 49.67 days for $50 \%$ flowering (Fig. 3). The earliest 50\% flowering was recorded from BARI Dherosh1 (44.33 day) which was at par with IPSA Okra (45.33 day),Arka Anamika (45.33days) and Hybrid Moti (45.33days) while late 50\% flowering were observed in Green Hybrid (49.67 days) and Hybrid Raja (49.67 days). The present result is in agreement with the findings of Reddy et al. (2012)

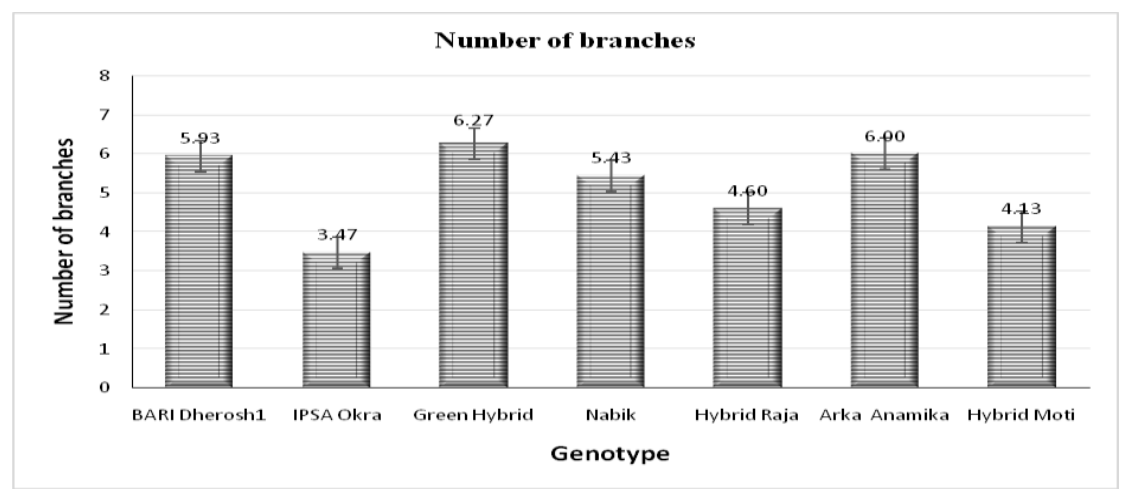

Fig. 1. Number of branches of seven genotypes of okra. 


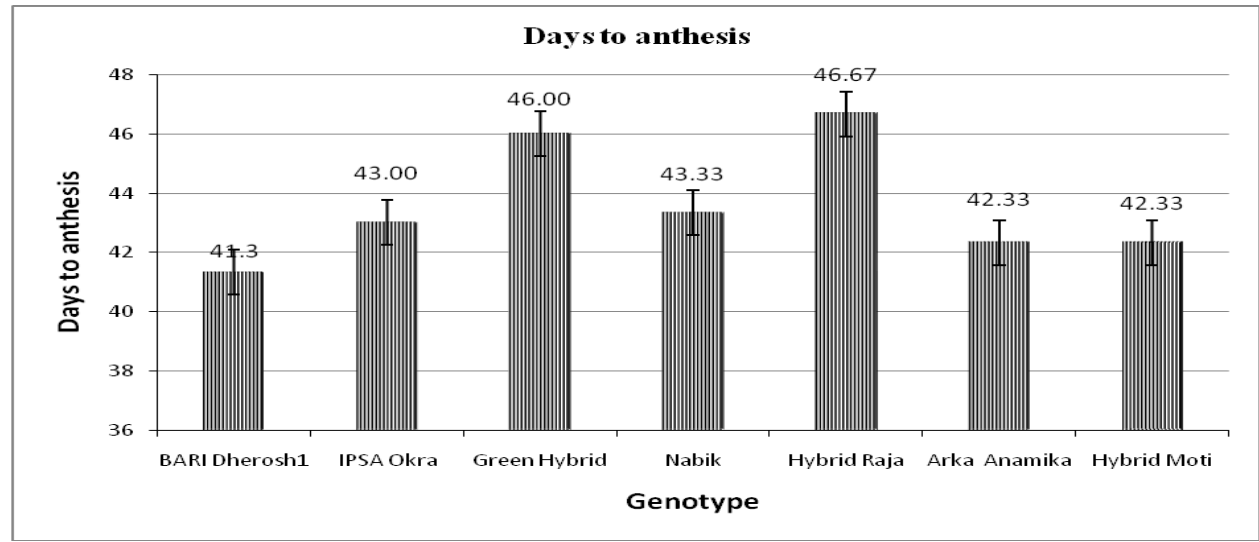

Fig. 2. Days to anthesis of different genotypes of okra.

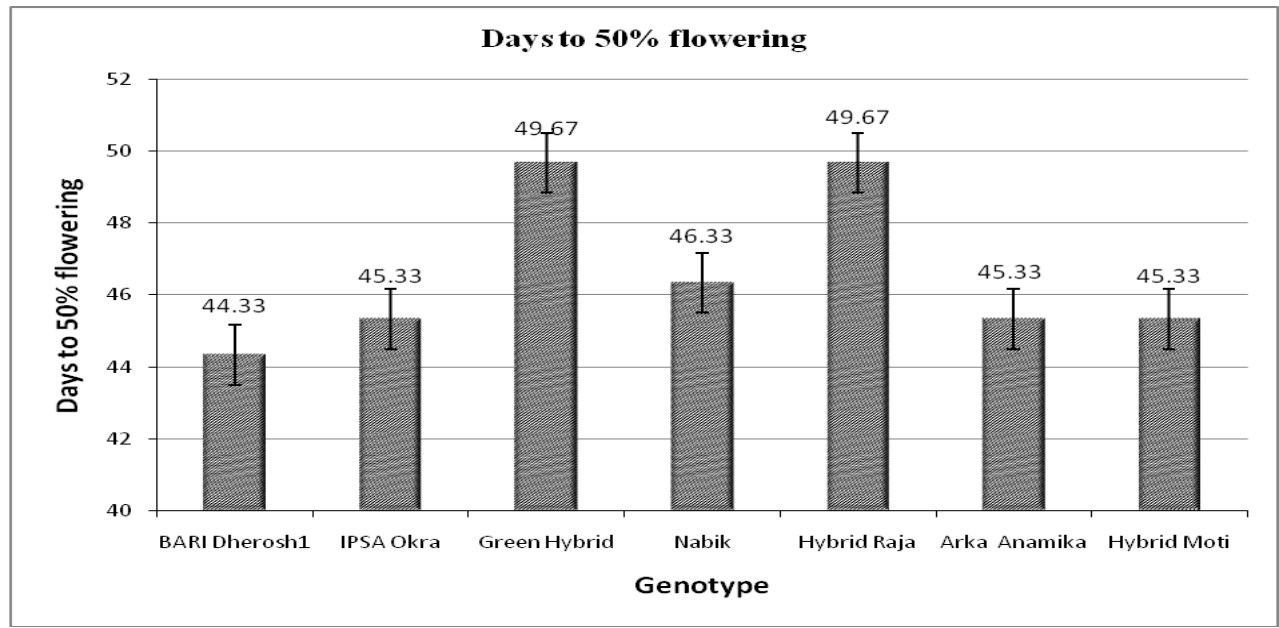

Fig. 3. Days to $50 \%$ flowering of seven genotype of okra.

\section{Fruit length (cm)}

Seven genotypes showed significant variation in respect of fruit length (Fig.4). The longest fruit length was observed in Arka Anamika $(13.80 \mathrm{~cm})$ followed by Hybrid Moti $(12.57 \mathrm{~cm})$, BARI Dherosh1 $(12.23 \mathrm{~cm})$. The fruit length of Green Hybrid $(9.13 \mathrm{~cm})$ was found to be shortest. This result was in agreement with the result obtained by Kuwar et al. (2001) who found that maximum fruit length were $13.86 \mathrm{~cm}$

\section{Fruit diameter (mm)}

Fruit diameter varied significantly among the genotypes (Fig.5). The widest fruit diameter found in genotype Arka Anamika $(17.83 \mathrm{~mm})$ which was at par with BARI Dherosh1 (17.06 mm.) and IPSA Okra (16.87 mm.) while Hybrid Raja 
(15.1 mm.) had the shortest fruit diameter and similar with genotypes Green Hybrid (15.65 mm.) and Nabik (16.14 mm.). Kuwar et al. (2001) reported that maximum fruit diameter were $14.7 \mathrm{~cm}$.

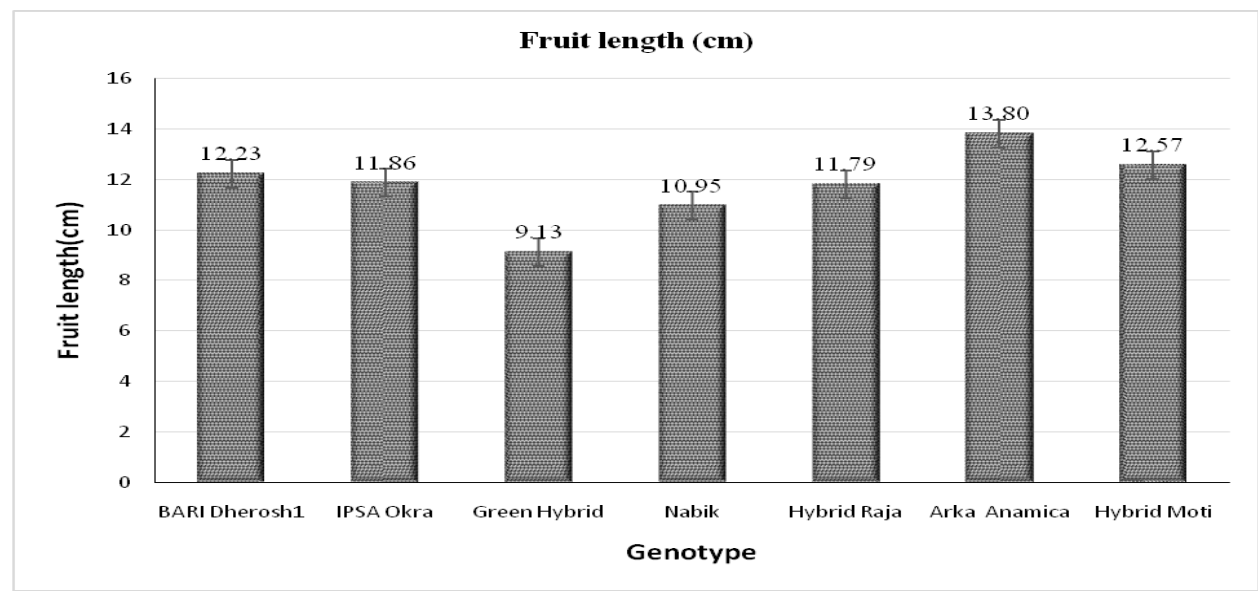

Fig. 4. Fruit length of different genotypes of okra.

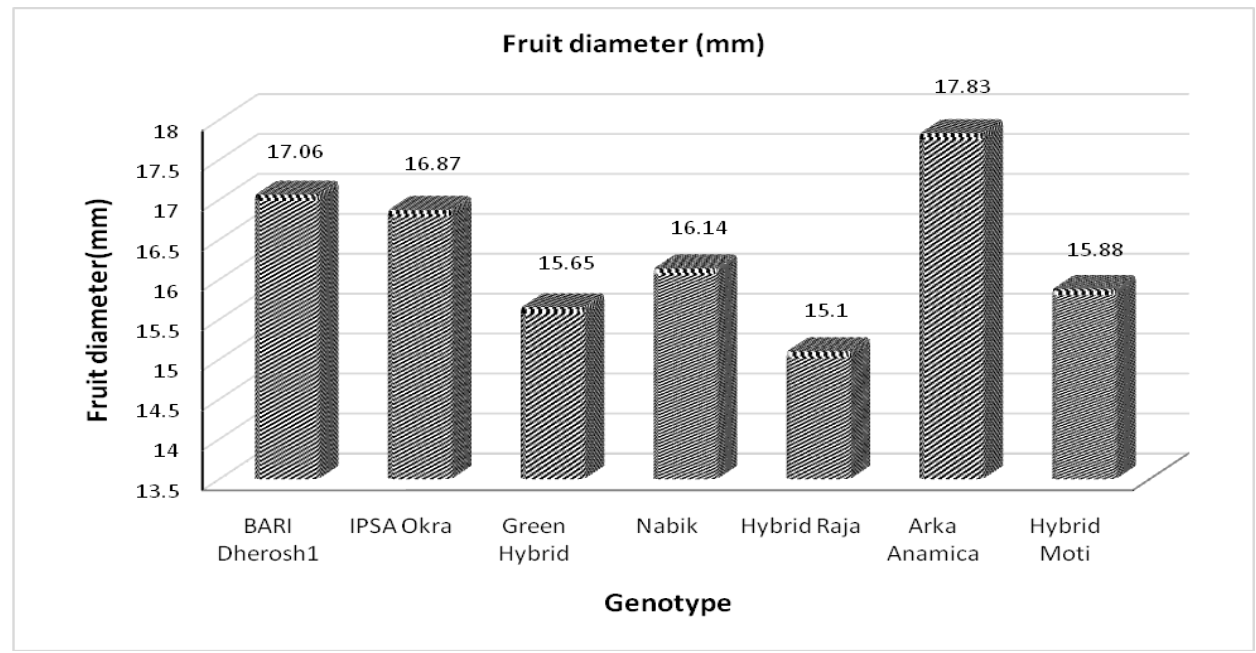

Fig. 5. Fruit diameter of seven genotypes of okra.

\section{Numbers of fruit per plant}

Fruit per plant varied significantly among the genotypes (Fig. 6). Fruit per plant in this study varied from 10.27 to 24.27. The highest fruits per plant ware recorded from BARI Dherosh1 (24.27). The genotype Green Hybrid (10.27) produced the lowest edible fruit per plant which was statistically identical with Hybrid Raja (11.27). The present result is within the range of the findings reported by Rahman et al. (2012). 


\section{Fruit weight (g)}

Significant difference was observed among the okra genotypes in respect of fruit weight (Fig. 7). Fruit weight varied from 12.31 to15.84 g. The highest fruit weight was observed in IPSA Okra $(15.84 \mathrm{~g})$ which was at par with Green Hybrid (15.44g), Nabik (15.45 g) and Arka Anamika (15.66 g). The lowest Fruit weight was observed in Hybrid Raja (12.31 g). This result was in agreement with the result obtained by Karri and Pinaki (2012).

\section{Picking duration (days)}

The seven genotypes showed significant variation in respect of picking duration (Fig. 8). Duration of picking in this study varied from days 36.33to 43.33 days. Among all genotypes, fruit harvesting continued for the longest period in case of BARI Dherosh1 (43.33 days). The genotypes Green Hybrid (41.33 days) and Arka Anamika (42 days) carried out longer time while the Nabik (36.33 days) had shortest duration.

\section{Yield per plant}

Fruit yield per plant differed significantly among the tested genotype (Fig. 9). Yield per plant in this study varied from 138.30 to $357.70 \mathrm{~g}$. The highest fruit yield per plant was observed in BARI Dherosh1 (357.70 g) which was at par with Arka Anamika (310.90 g) and Hybrid Moti (281.50 g). The lowest fruit yield per plant was observed in Hybrid Raja (138.30 g). Reddy et al. (2012) reported that yield per plant was $242.61 \mathrm{~g}$. The present result is within the range of reported result. Yield per plant probably vary due to genotype, management practice, number of fruit per plant fruit length, fruit diameter etc.

\section{Yield (t/ha)}

The fruit yield significantly varied ranging from $5.76 \mathrm{t} / \mathrm{ha}$ to $14.90 \mathrm{t} / \mathrm{ha}$ among the genotypes (Fig. 10).The genotype BARI Dherosh1 (14.90 t/ha) produced the highest yield which was at par with Arka Anamika (12.95 t/ha) and Hybrid Moti (11.73 t/ha). The lowest yield was found in Hybrid Raja (5.76 t/ha). These results are in full conformity with Rahman et al. (2012), Firoz et al. (2011) and Amanullah et al. (1999) who found significant varietal differences in yield.

\section{Dry weight (\%)}

Dry weight varied significantly among the genotypes (Fig. 11). Dry weight varied in this experiment 12.28 to $19.90 \%$. The highest dry weight was observed in IPSA Okra (19.9\%).While lowest dry weight was observed in Hybrid Raja $(12.28 \%)$ followed by Green Hybrid $(13.13 \%)$. 


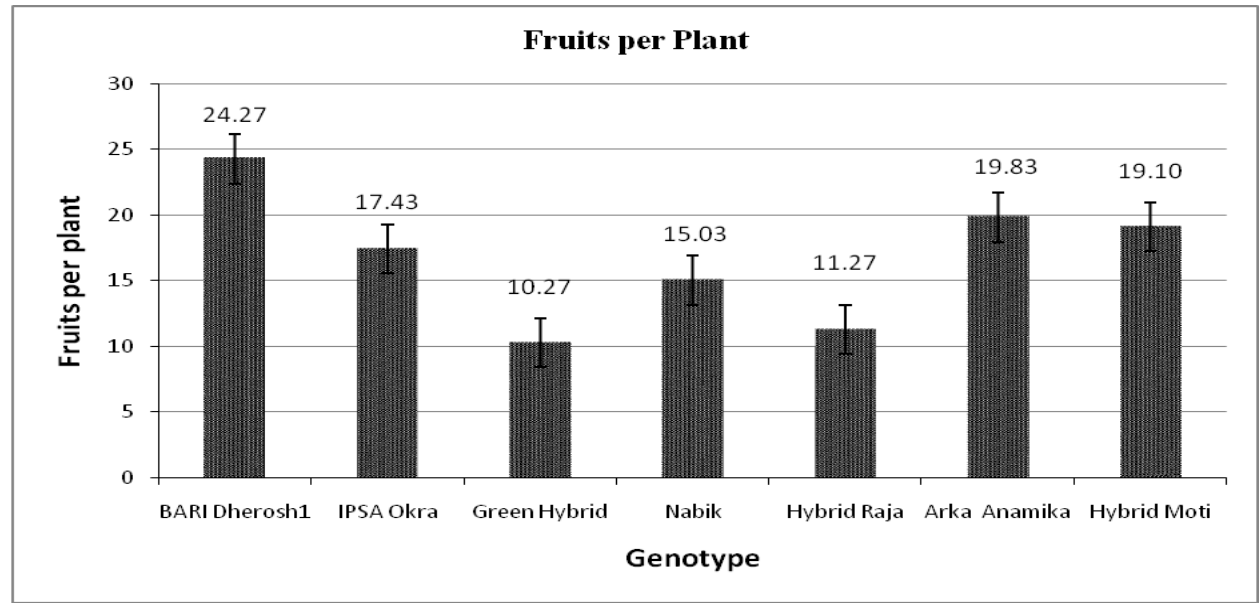

Fig. 6. Fruits per plant of seven genotypes of okra.

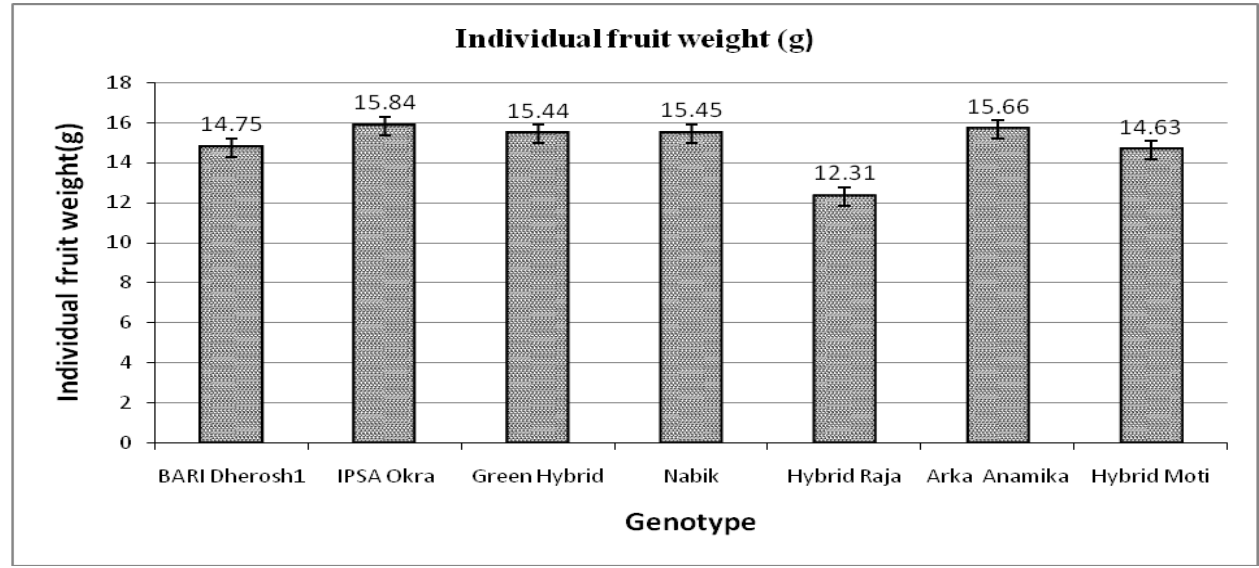

Fig. 7. Individual fruit weight of different genotypes of okra.

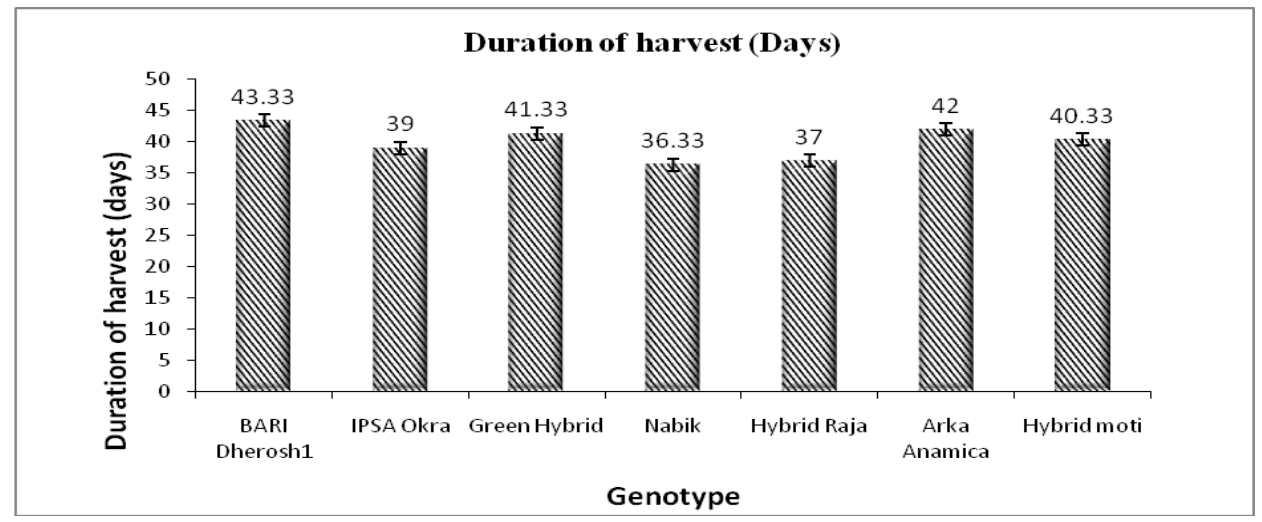

Fig. 8. Duration of harvest of seven genotype of okra. 


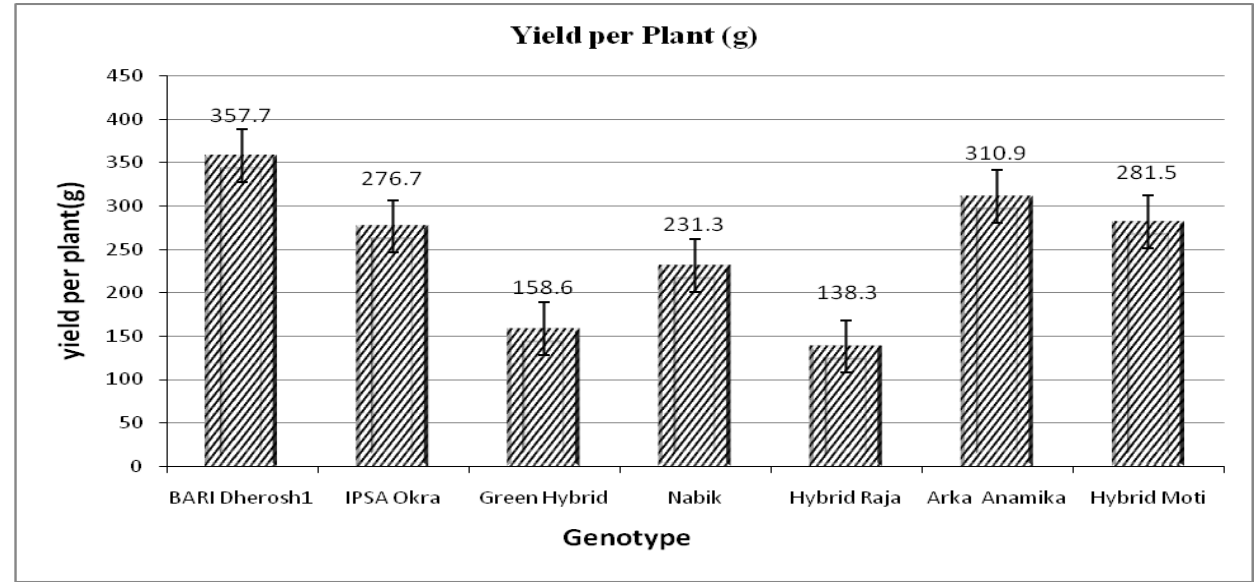

Fig. 9. Yield per plant of seven genotypes of okra.

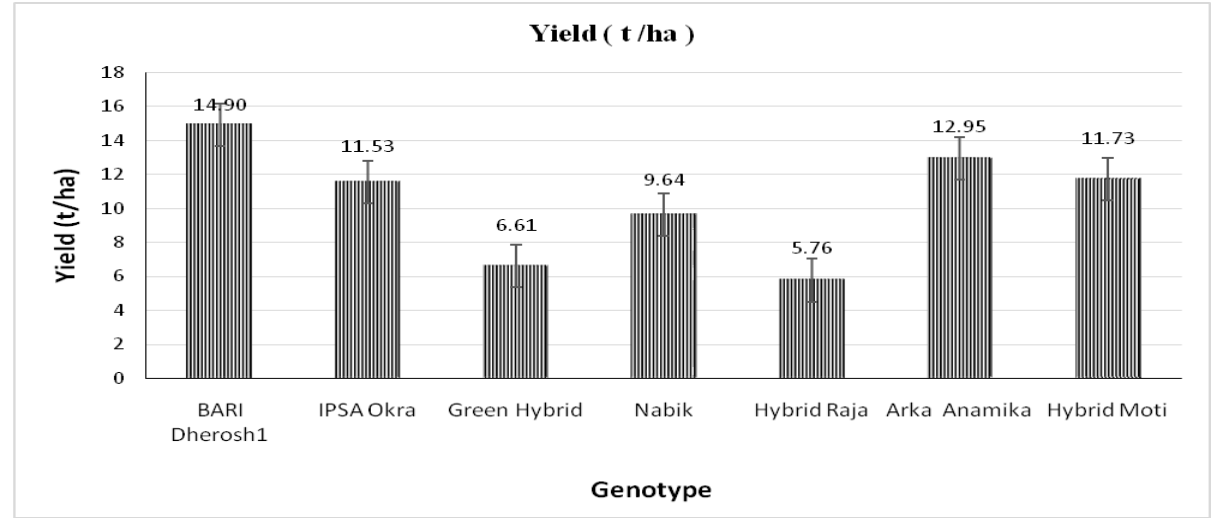

Fig. 10. Yield of seven genotypes of okra.

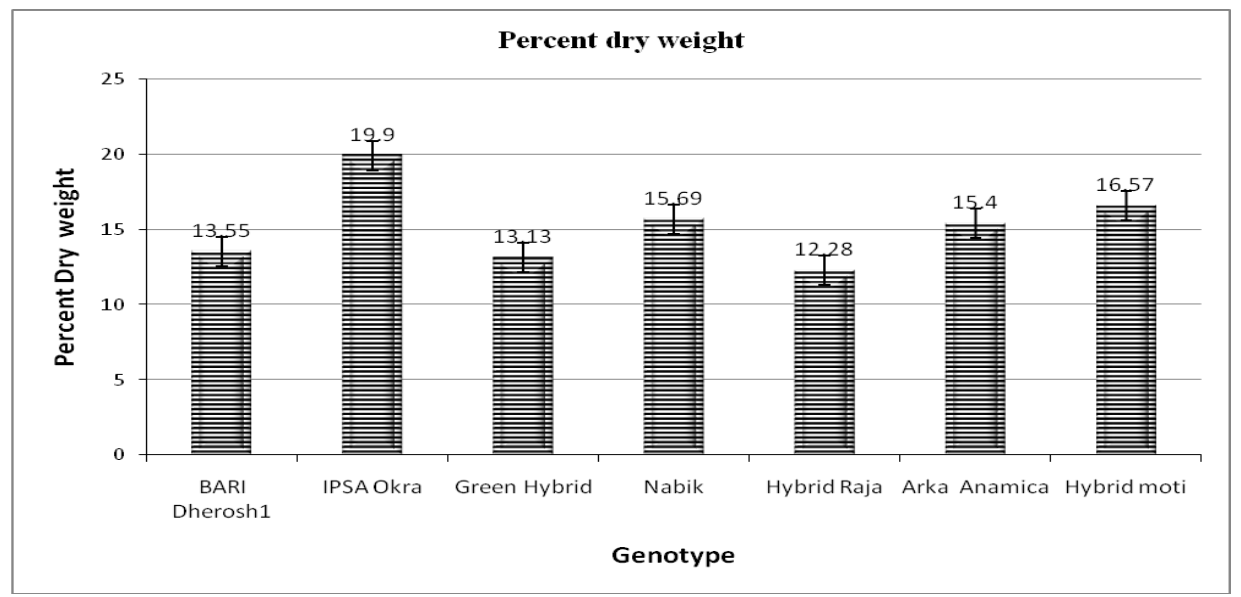

Fig. 11. Percentdry weight of seven genotypes of okra. 


\section{Virus Infestation (\%)}

Significant variation was observed among the genotypes in respect of virus infestation (Table 3). After germination of seedling there was no virus infested plant in experimental plot. With the increases of days infestation of virus was higher. There was no significant variation of virus infestation among the genotypes at 45 DAS.

The highest virus infestation was observed in Hybrid Raja (50\%) which was statistically identical with BARI Dherosh1 (43.33\%) and Green Hybrid (40\%). The lowest virus infestation was observed in Arka Anamika (23.33\%) which was statistically identical with IPSA Okra (30\%), Nabik (36.67\%) and Hybrid Moti (36.67\%) at 60 DAS. The Range of virus infestation was $50 \%$ to $23.33 \%$ at 60 DAS.

At 75 DAS highest virus infestation was observed in Hybrid Raja (76.67\%) which was statistically identical with Green Hybrid (73.33\%), Hybrid Moti (73.33\%) and Nabik (70\%). The lowest virus infestation was observed in Arka Anamika (53.33\%) which was statistically identical with IPSA Okra (60\%) and BARI Dherosh1.The range of virus infestation at 75 DAS was $76.67 \%$ to $53.33 \%$.

At 90 DAS highest virus infestation was observed in Hybrid Raja (100\%) which is statistically identical with Hybrid Moti (96.67 \%), Green Hybrid (93.33\%) and BARI Dherosh 1 (90\%).Lowest virus infestation was observed in ArkaAnamika (76.67\%) which was statistically identical with IPSA Okra (83.33\%) and Nabik $(83.33 \%)$. Mathew et. al., (2005) recorded in an investigation of six resistant variety of okra and infestation of virus varied from $2.31 \%$ to $54 \%$. Reddy et al. (2012) reported that the highest incidence of yellow vein mosaic virus on plants was observed in genotype of IC043279-A and IC043751-B (60.00\%), while the lowest for the genotypes IC90210 and IC018530 (30.00\%). The present result is higher than reported result due to different genotype.

Table 3. Virus infestation of seven okra genotypes at different days after sowing

\begin{tabular}{l|c|c|c|c}
\hline \multirow{2}{*}{\multicolumn{1}{c}{ Genotype }} & \multicolumn{5}{c}{ Virus infestation (\%) } \\
\cline { 2 - 5 } & $45 \mathrm{DAS}$ & $60 \mathrm{DAS}$ & $75 \mathrm{DAS}$ & $90 \mathrm{DAS}$ \\
\hline BARIDherosh 1 & 10.00 & $43.33 \mathrm{ab}$ & $63.33 \mathrm{bc}$ & $90.00 \mathrm{ab}$ \\
IPSA Okra & 13.33 & $30.00 \mathrm{bc}$ & $60.00 \mathrm{bc}$ & $83.33 \mathrm{bc}$ \\
Green Hybrid & 16.67 & $40.00 \mathrm{ab}$ & $73.33 \mathrm{ab}$ & $93.33 \mathrm{ab}$ \\
Nabik & 13.33 & $36.67 \mathrm{bc}$ & $70.00 \mathrm{ab}$ & $83.33 \mathrm{bc}$ \\
Hybrid Raja & 16.67 & $50.00 \mathrm{a}$ & $76.67 \mathrm{a}$ & $100.0 \mathrm{a}$ \\
ArkaAnamika & 10.00 & $23.33 \mathrm{c}$ & $53.33 \mathrm{c}$ & $76.67 \mathrm{c}$ \\
Hybrid Moti & 10.00 & $36.67 \mathrm{bc}$ & $73.33 \mathrm{ab}$ & $96.67 \mathrm{ab}$ \\
Level of significance & NS & $*$ & $*$ & $*$ \\
CV\% & 34.64 & 22.88 & 11.41 & 8.72 \\
\hline
\end{tabular}

Means bearing same letter(s) in a column do not differ significantly at $5 \%$ level of probability by DMRT. 


\section{Nutritional effect among the okra genotypes}

\section{Ascorbic acid}

Ascorbic acid content varied significantly among the genotype. Ascorbic acid content in this study varied from 3.35 to $1.99 \mathrm{mg} / 100 \mathrm{~g}$ (Table 4). The highest content of free ascorbic acid was recorded in Nabik $(3.35 \mathrm{mg} / 100 \mathrm{~g})$ which was statistically identical with Hybrid Moti $(3.173 \mathrm{mg} / 100 \mathrm{~g})$ while lowest ascorbic acid content was observed in Green Hybrid $(1.987 \mathrm{mg} / 100 \mathrm{~g})$. Kokare et al. (2006) reported that highest amount of ascorbic acid content was $17.35 \mathrm{mg} / 100$ $\mathrm{mg}$. The present result is quite lower than the reported result.

\section{$\beta$-carotene}

Significant variations in the amount of $\beta$-carotene were found, when considered different genotype effect. It varied from 0.09 to $0.15 \mathrm{IU} / 100 \mathrm{~g}$ (Table 4). Hybrid Moti had the maximum amount of $\beta$-carotene $(0.15 \mathrm{IU} / 100 \mathrm{~g})$, while minimum amount of $\beta$-carotene was found in IPSA Okra (0.09 IU/100 g).

Table 4. Vitamin and mineral content of seven genotypes of okra

\begin{tabular}{l|c|c|c|c}
\hline \multicolumn{1}{c}{ Genotype } & $\begin{array}{c}\text { Ascorbic Acid } \\
(\mathrm{mg} / 100 \mathrm{~g})\end{array}$ & $\begin{array}{c}\beta \text {-carotene } \\
\mathrm{IU} / 100 \mathrm{~g}\end{array}$ & $\mathrm{~K}(\%)$ & $\mathrm{Fe}(\mathrm{ppm})$ \\
\hline BARIDherosh 1 & $2.91 \mathrm{c}$ & $0.14 \mathrm{~b}$ & $1.09 \mathrm{ab}$ & $111.80 \mathrm{c}$ \\
IPSA Okra & $2.93 \mathrm{c}$ & $0.09 \mathrm{e}$ & $1.09 \mathrm{a}$ & $132.60 \mathrm{ab}$ \\
Green Hybrid & $1.99 \mathrm{e}$ & $0.10 \mathrm{~d}$ & $1.09 \mathrm{ab}$ & $111.80 \mathrm{c}$ \\
Nabik & $3.35 \mathrm{a}$ & $0.11 \mathrm{c}$ & $1.08 \mathrm{c}$ & $124.00 \mathrm{~b}$ \\
Hybrid Raja & $2.64 \mathrm{~d}$ & $0.10 \mathrm{~d}$ & $1.07 \mathrm{~d}$ & $132.60 \mathrm{ab}$ \\
ArkaAnamika & $3.08 \mathrm{bc}$ & $0.10 \mathrm{~d}$ & $1.08 \mathrm{~b}$ & $127.40 \mathrm{~b}$ \\
Hybrid Moti & $3.17 \mathrm{ab}$ & $0.15 \mathrm{a}$ & $1.09 \mathrm{a}$ & $139.60 \mathrm{a}$ \\
Level of significance & $*$ & $*$ & $*$ & $*$ \\
CV\% & 4.00 & 5.38 & 1.13 & 4.61 \\
\hline
\end{tabular}

Means bearing same letter(s) in a column do not differ significantly at 5\% level of probability by DMRT.

\section{Potassium (K \%)}

Significant variation in the amount of $\mathrm{K} \%$ was varied significantly among the genotypes. It varied from $1.066 \%$ to $1.091 \%$ (Table 4). The highest $\mathrm{K} \%$ was observed in IPSA Okra (1.091\%) which was statistically identical with Hybrid Moti $(1.09 \%)$ and Green Hybrid (1.088 \%). The lowest K \% was observed in Hybrid Raja (1.07 \%). Ubi and Osodeke (2006) reported that amount of potassium recorded as $302 \mathrm{mg} / \mathrm{kg}$ or $0.03 \%$ which is much lower than the findings of present study. 


\section{Iron $(\mathrm{Fe})$}

Amount of iron varied significantly among the genotype. Amount of iron varied from 139.6 to $111.8 \mathrm{ppm}$ (Table 4). The highest amount of Fe was observed in Hybrid Moti (139.6 ppm) which was statistically identical with IPSA Okra (132.6 ppm) and Hybrid Raja (132.6 ppm). The lowest amount of Fe was observed in Green Hybrid (111.8 ppm). Midrar et al. (2005) reported slightly higher amount $(120.9 \mathrm{mg} / \mathrm{kg})$ of $\mathrm{Fe}$ in Okra.

\section{Conclusions}

The result of present study generated some information which may help on efficient vegetable production. Among the seven genotypes, BARI Dherosh1 was the highest yielder, which had the maximum number of fruit per plant. Arka Anamika was second highest yielder and minimum virus infection. The highest percent of dry matter was obtained from IPSA Okra. None of the variety was found resistant against virus infestation. Nutritional status such as ascorbic acid, $\beta$-carotene, iron, and potassium of okra varied significantly among the genotypes. The present results revealed that the yield was maximum in BARI Dherosh1 while Hybrid Moti was superior in nutritive value.

\section{References}

Amanullah, J. R. Shahid and M. A. Khokhar. 2000. Competitive yield performance of okra cultivars under Islamabad condition. Sarhad Journal of Agriculture. 15(1):13-141.

Duvauchelle, J. 2011. "Okra Nutrition Information". LiveStrong.com. Retrieved 24 June 2012.

Firoz, Z. A. 2009. Impact of nitrogen and phosphorus on the growth and yield of okra (Abelmoschus esculentus (L.) Moench) in hill slope condition. Bangladesh Journal of Agricultural Research. 34(4): 713-722.

Franklin, W. M. 1982. "Okra, Potential Multiple-Purpose Crop for the Temperate Zones and Tropics". Economic Botany. 36(3): pp.340-345

Gomez, K. A. and A. A. Gomez. 1984. Statistical Procedures for Agricultural Research. (2nd Edition). John Willy and Sons, New York. Pp. 28-192.

Karri, S. K. and A. Pinaki. 2012. Performance of okra (Abelmoschus esculentus (L.) Moench) cultivars under summer and rainy environment. International Journal of Advance life Science. 2: 16-26.

Kokare, R. T.; R. K. Bhalerao; T. Prabu; S. K. Chavan; A. B. Bansoda and G. S. Kachare. 2006. Effect of plant growth regulators on growth, yield and quality of okra [Abelmoschus esculentus (L.) Moench]. Agricultural Science Digest. 26(3): 178-181

Kuwar, R. P.; K. J. Kubde; S. D. Malvi; S. T. Dangore and P. D. Rault. 2001. Response of okra genotypes to varying plant density. Pakistan Research Journal. 25(1):65-67.

Mathew, S. K.; M. A. Vahab; V. S. Devadas and Cherian. 2005. Evaluation of selected varieties of okra for yield and resistance to yellow vain mosaic. Journal of Tropical Agriculture. 31(2): 215-218 
Midrar, U. H.; R. A. Khattak; H. K. Puno; M. S. Saif; K. S. Memon and N. B. Sial. 2005. Bioaccumulation of trace elements by different plant species grown on potentially contaminated soils of NWFP, Pakistan. Asian Journal of Plant Sciences. 4(4): 383-387.

Muhammad, A.; S. Muhammad; M. A. Anjum; C. M. Ayyub and M. Muhammad. 2001. Comparative study on the performance of some exotic okra cultivars. International Journal of Agriculture and Biology. 3(4):423-425.

Rahman, K; K. Waseem and M. Masum-ur-Rashid. 2012. Performance of different okra (Abelmoschus esculentus) cultivars under the agro climatic conditions of Dera Ismail Khan. Pakistan Journal of Time. 64(4); pp.316-319

Rashid, M. M. 1999. Shabji bijjayan (In Bengali). Rashid Publishing House, 94, Old DOHS, Dhaka-1206. P. 476.

Reddy, M. T.; K. Haribabu; M. Ganesh; K. C. Reddy and H. Begum. 2012. Genetic divergence analysis of indigenous and exotic collections of okra (Abelmoschus esculentus (L.) Moench). Journal of Agricultural Technology. 8(2): 611-623.

Schippers, R. R. 2002. African indigenous vegetable an overview of the cultivated species. National Resources Institute (NRI), University of Greenwich, London, united Kingdom. Pp. 214.

Siemonsma, J. S. and C. Kouame, 2004. Vegetables in plant resource of tropical Africa. 2. Pp. 21-29.

Tindall, H.D. 1983. Vegetables in the tropics. Macmillan press Ltd. London and basilgstoke. Pp.25-328.

Ubi, W. and V. E. Osodeke. 2006. Extraction of macronutrients from okra (Abelmoschus esculentus (L) Moench) as influenced by some mulch materials in the acid sands Global Journal of Pure and Applied Sciences. 12(4): 443-447. 